\title{
Construction of Sexual Identity and Expression of Semarang Adolescents in the Global Economy: A City Ethnographic Adolescent Approach
}

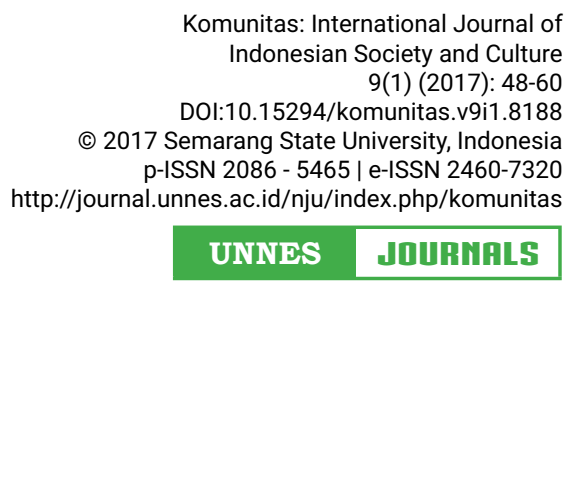

Komunitas: International Journal of (1) $(2017): 48-60$ unitas.v9i1.8188 7 Semarang State University, Indonesia UNNDS JDURNALS

\section{Harto Wicaksono ${ }^{1}$, Noviani Achmad Putri' ${ }^{2}$, Nurul Fatimah ${ }^{3}$}

1,2,3Sociology Department, Faculty of Social Sciences, Universitas Negeri Semarang, Central Java, Indonesia

Received: 9 December 2016; Accepted: 21 March 2017; Published: 30 March 2017

\begin{abstract}
Liminal identity is a problem faced by adolescence. Liminal events occur due to the reluctance of parents to share adolescent experiences with teenagers in the family. In addition to the transition period, the most noticeable development in adolescence is its physical growth. Physical growth is accompanied by an active hormone that influences the curiosity of adolescents about physical changes, psychological, and biological desires. This study aims to understand the construction of identity and sexual expression of adolescents in Semarang. This research employed descriptive qualitative research. The results of the study indicate that an inappropriate distribution of adolescents' curiosity brings great consequences during adolescence period. Many adolescents express themselves by having sex outside of marriage and other sexual behaviors. This occurs as a result of wrong association and inaccurate distribution of curiosity. Misconceptions of adolescent behavior also happen due to misconceptions and miss-adaptation of the environment. The behavior is heavily influenced by their environment where they grow and develop, especially in the urban environments which are very complex due to global dynamics.
\end{abstract}

\section{Keywords}

identity construction; adolescent sexuality; global economy

\section{INTRODUCTION}

According to the World Health Organization (WHO), adolescence is a period in the development of human life which lies from age 10 to 19 years old (WHO 1986). In this particular age range, adolescents/teenagers will experience a physical development and change quickly. Therefore, they will visually have the same reproductive organs with adults. This rapid growth is not supported by appropriate knowledge, especially about the symptoms experienced by adolescents with their physical growth. Such big curio- sity dealing with their physical growth and symptoms makes teenagers channel their curiosity by experimenting with their reproduction organs.

To respond to their body growth symptoms, adolescents also access the internet a lot to find answers about the questions related to the physical and psychological conditions that they encounter. In the article

\footnotetext{
Corresponding author

C7 Building, $1^{\text {st }}$ Floor, Faculty of Social Sciences,

Universitas Negeri Semarang, Central Java, Indonesia Email

hartowicaksono@mail.unnes.ac.id
} 
of Soejoeti, it is explained that adolescents access a lot of cyberspace that presents the spectacle and read about sex, both from local and foreign websites. The ease to access websites which provide pornography contents without guidance from parents or practitioners in the field will lead to errors in the process of meaning and response to the view that they see. According to Soejoeti, sexual behavior that deviates is much influenced by environmental factors and pornographic contents (Soejoeti 2001, p. 30; MaikovichFong 2010; Renaud 2010).

The growth of adolescents with high levels of information needs related to their sexuality cannot be found in a family room. Ironically, family circle is not able to serve the needs of adolescents to be responsible in having appropriate knowledge and healthy reproductive organs. Under these conditions, adolescents try to find out those symptoms from outside of their house, both from friends and on the internet. Especially with today's level of technological sophistication using smartphone, adult-category sites turn into easy spaces for them to satisfy their curiosity that leads to teenage promiscuity. According to Astuti, 1 in 4 Indonesian adolescents undergo free sex, even based on BKKBN research in 2008, adolescents in major cities of Indonesia show that $63 \%$ of teenagers have committed free sex (Magdalena 2010, p. 4; Calzo 2011; Stone 2014; Everett 2013).

The inappropriate distribution of curiosity brings great consequences to the adolescent behavior becoming adults. Many adolescents have conducted sex outside of marriage due to wrong association and distribution of curiosity about their physical and psychological conditions. Within this period, adolescents are in the search for identity. The identity becomes a crucial area. If adolescents have proper control and awareness of their social and cultural conditions in where they live, they will be able to find space and identity that are compatible with their personality. However, if adolescents are dragged into the flow of global dynamics that tends to deify freedom, especially in terms of expressing their sexuality, they will lose their teenage years (DiFulvio 2011;
Burton 2013; Walls 2010; Ringrose 2011).

Families who are supposed to be primary knowledge agents do not function properly. Hence, adolescents tend to look for answers about what they feel outside their family. The irony of the role of parents is that it is only oriented on the level of economic needs for their children, while being a socialization agent on the growth of sexuality becomes blurred. This also happens because of the assumption that when their children ask about sexuality, it is still considered taboo under the values construction of Indonesian society. In addition, according to Putri, most of adolescents who are nurtured permissively have done premarital sexual behavior at moderate risk (Princess 2014).

Several researches which have been done previously by Synanti and Soejoeti (2001), Yulianto (2010), Wulandari (2010), Kusumastuti (2010), Suryanto and Kuwatono (2010), Purwandari (2011), Princess (2014), Oljira, Berhane and Worku (2012) and Cherie and Berhane (2012) show that the problems faced by adolescents in supporting their growth are very complex. The support from family and community in supporting the success of growth and development is inevitable, in addition to the approach from the medical side.

Therefore, it can be seen that the way adolescents express their identity and sexual is much influenced by the role of the family: the smaller the role of families in providing knowledge about teenage sex, the bigger chance for adolescents to seek the knowledge outside their home. The search for information outside their home occurs because the role of the global era family only focuses on the level of material needs. The phenomenon also commonly happens to adolescents in urban areas, especially in Semarang which becomes the research site. The above basic assumptions are the underlying considerations for researchers to reveal how the ethnography of families and adolescents in urban areas in responding adolescent sexuality.

Based on the earlier basic assumption of social reality, the problem of research is formulated: "how do adolescents in Semarang express their sexual identity?" This is also 
influenced by the process of enculturation done by their family and environment. The present study observes at the socio-cultural constructions that occur in connections between adolescents, families and environments in reconstructing/establishing urban identity of adolescent. The issues expressed are presented in the perspective of sociology and anthropology. This understanding would be rightly used to uncover the space for the formation of the identity of urban teenagers over adolescent sexuality.

The subjects in the study were adolescents who were constructing their identity and sexuality in urban areas, particularly the adolescents and families in Semarang. The mentioned adolescent informants were high school students (SMA) both in public and private schools in Semarang. And, the parents were the informants' parents. The decision to involve this informant parents was to crosscheck what was conveyed by adolescents who were selected as informants. To shed light on how adolescents express their identity, a comprehensive study was needed. Therefore, in addition to the research carried out directly, crosschecking the status and profile picture of the subject was essential. In order for the results of research could be holistic, then it was also important to see how the role of urban families in the global economic currents put their adolescents who were experiencing growth to adulthood.

Data collection techniques began with literature study, observation and interviews. The data collection system that researchers used referred to one saturation principle. If the data obtained from the informant had not provided any new information, then the interview was terminated because it was considered sufficient (Schensul, Schensul, \& Le Compte 1999, p. 262).

In the process of data analysis, there were major components that had to be fully understood, i.e. data reduction, data presentation and conclusion or verification (Sutopo in Rachman 1999, p. 34). To analyze various existing data, researchers used analytic descriptive method. Data analysis was done qualitatively and inductively together with data collection process. Further, in the process of analysis, the present study employed an analytical approach with analytical ethnographic using thick description.

\section{Perceptions of Sexuality among Se- nior High School Students}

The adolescent's understanding of teenage sexuality with each other is different. The emergence of differences in perception is caused by several factors. Based on the results of present study, there are two perceptions about sexuality: negative perceptions and positive perceptions. The first perceptions deal with the perception of positive sexuality, where the perceptions of sexuality refer to good and responsible sexuality in accordance with the values and norms prevailing within society. The second perceptions deal with the perception of negative sexuality, where the perceptions of sexuality re synonymous with premarital sexual behavior. The difference between these two perceptions is influenced by several factors. These factors include: knowledge and information, economic condition, culture, religion, dating experience.

Based on the above presentation, Figure 1 contains the factors that influence the
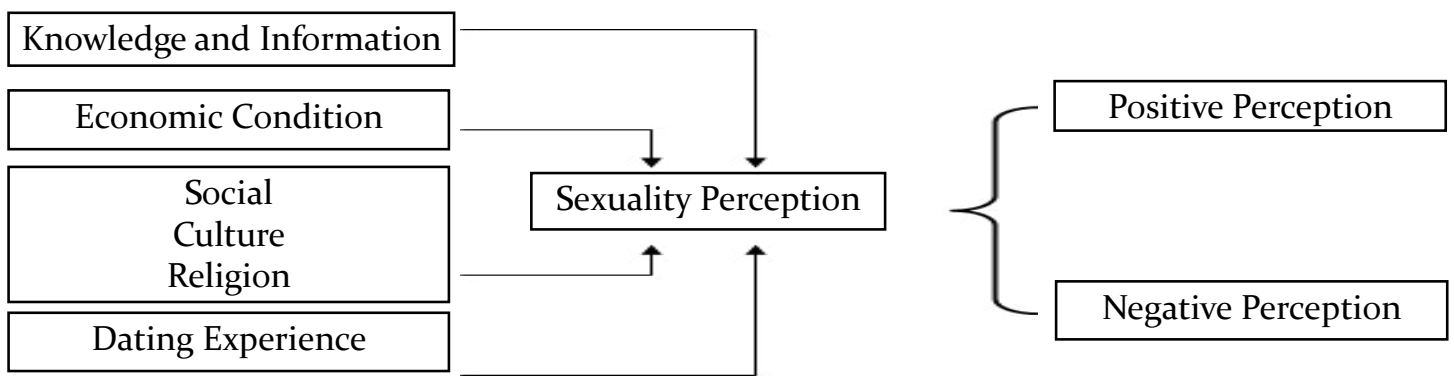

Figure 1. Influencing Factors which Impact the Sexuality Perception among Students Source (Research 2015) 
adolescents' perception on sexuality. These factors include: knowledge and information, economic conditions, socio-cultural environments and dating experience. Each factor contributes tremendously to the formation of sexuality perceptions among adolescents. Most communities, both rural and urban, have different perceptions of sexuality. Developing perceptions can be categorized into two groups: the first is that talking about sexuality is considered taboo and unfit for discussion, and the second is the assumption that sexuality is important and worth discussing.

One of the dominating factors is social, culture and religion that surrounds every society. The level of understanding of one's religion greatly affects the process of socialization of parents to children in relation to the introduction of sexuality topic. Sometimes, some people think that talking about sexuality is something taboo to reveal. As response to it, adolescents usually tend to steal information through other information channels. Different case occurs in a society that is quite open about sex edu-

Table 1. Perceptions of Positive Sexuality

\begin{tabular}{|c|c|}
\hline No & Perceptions of Positive Sexuality \\
\hline 1. & $\begin{array}{l}\text { Sexuality is something that cannot be separated from sexual behavior. This sexual be- } \\
\text { havior can only be done by a married couple through an official institution called a mar- } \\
\text { riage institution. Related to the function of sexuality itself, the students assume that the } \\
\text { behavior of sexuality done after a marriage bond aims to continue the descent and is not } \\
\text { just a momentary lust as it commonly happens especially among the students. }\end{array}$ \\
\hline 2. & $\begin{array}{l}\text { Sexuality today is more prone to premarital sex. Premarital sex behavior is indecent and } \\
\text { embarrassing behavior, destructive to the dignity of parents, hurting the feelings of any- } \\
\text { one who hears it and unlawful with religious teachings. Premarital sex behavior among } \\
\text { students can also provide examples that are not good for other students. }\end{array}$ \\
\hline 3. & $\begin{array}{l}\text { Sexuality which involves touching, kissing, kissing and hugging should only be done by } \\
\text { a male and female couple who are legally married and in accordance with religious de- } \\
\text { mands in doing so, and must consider the norms that exist in society. }\end{array}$ \\
\hline 4. & $\begin{array}{l}\text { Good sexuality serves as a prohibition on premarital sexual behavior. The existence of } \\
\text { such rule on premarital sexual behavior is because in religion, it is clearly prohibited and } \\
\text { considered as a sin. Besides, it can also have a negative impact on health and social life } \\
\text { of someone. }\end{array}$ \\
\hline 5 . & $\begin{array}{l}\text { Sexuality is associated with sexual behavior. However, sexual behavior can only be } \\
\text { done by a husband and wife who are married through an official institution called mar- } \\
\text { riage. The function of such sexuality behavior through marriage bond aims to continue } \\
\text { the offspring and is not just a shortage of lust as it commonly happens among students. }\end{array}$ \\
\hline 6. & $\begin{array}{l}\text { Sexuality is closely related to the prohibition of premarital sexual behavior. The existence } \\
\text { of prohibition of premarital sexual behavior is important as it is prohibited by religion } \\
\text { and it also has some negative impacts for health and social life. }\end{array}$ \\
\hline 7. & $\begin{array}{l}\text { Students' perceptions of sexuality show that sexuality is identical to sexual behavior. The } \\
\text { behavior can only be done by men and women couples who have been united by formal } \\
\text { marriage bonds. }\end{array}$ \\
\hline 8. & $\begin{array}{l}\text { Sexuality is something taboo. The talk on sexuality should be discussed to the right peo- } \\
\text { ple like parents and experts. }\end{array}$ \\
\hline 9. & $\begin{array}{l}\text { Talking about sexuality is not simply revealed and even carried out easily, but they must } \\
\text { consider where, when, who will do the sexual behavior itself. It is based on the values and } \\
\text { norms prevailing within society. }\end{array}$ \\
\hline
\end{tabular}

Source: Primary Data Processing (2015) 
cation. Such families usually have more frequent open communication and provide a proper channel for adolescents who are starting to have a high curiosity.

The results in the field suggest that some students construct sexuality as a negative topic. This perception difference cannot be separated from the factors that exist in picture 1. In order to facilitate the reader in knowing the perception of negative sexuality among high school students, the researchers try to present the data in a table. Here is the result of negative sexual perception among high school students in Semarang:

Perceptions about sexuality based on pre-marital sexual knowledge can influence the attitudes or behavior of the individual to premarital sexual. Adolescents who get the right information about sexuality tend to have a positive attitude or stay away from things that lead to premarital sex beha- vior. Meanwhile, adolescents who are lack of knowledge about premarital sexual tend to have a negative attitude, which is close to the things that lead to premarital sexual behavior. The high school students in Semarang have partly done premarital sexual behavior. This is due to the perception and knowledge of the students about the wrong sexuality caused by socio-cultural conditions of student residence. The perceptions of sexuality, both positive and negative, are perceptions that apply to adolescents in Semarang. Such perceptions really influence the pattern and expression of sexual behavior of adolescents in Semarang.

\section{Sexual Expressions and Terms of Adolescents toward Age and Sexual Maturity}

There are varieties of ways for adolescents to respond the age and growth of their

Table 2. Perceptions of Negative Sexuality

\begin{tabular}{cl}
\hline No & \multicolumn{1}{c}{ Perceptions of Negative Sexuality } \\
\hline 1. & Sexuality is all behaviors that are driven by sexual desire, either with the opposite sex or \\
with same sex. Sexuality is ranging from interested feeling to dating, kissing, and inter- \\
course activity. \\
2. Sexuality is synonymous with activities related to the impulse of sexual desire such as kiss- \\
ing, touching and even intercourse by those who have not legitimately become husband \\
and wife. \\
3. Sexuality is a form or expression of affection that is done by boyfriends or partners who \\
are in love. \\
4. Sexuality is a form of freedom of expression committed by couples who love each other. \\
5. Sexuality is synonymous with premarital sexual behavior. Sexual behavior is an attempt of \\
proof done by adolescent couples who love each other by doing sexual activity. \\
6. Sexual behavior can give an additional sense of pleasure for a person. This premarital \\
sexual intercourse can be done with ordinary friends. Sex also aims to establish relation- \\
ships and most importantly, to satisfy someone's sexual desire. \\
7. Sexuality is an activity of sex behavior that a person does with a partner either in a mar- \\
riage bond or outside a marriage bond. Premarital sexual behavior may last as long as it \\
is unknown and will not get sanction from the community members where the student \\
lives. If there is no strict prohibition from members of the community especially from \\
their neighbors, students are quite safe and do not receive heavy violation. \\
8. Sexuality is associated with premarital sexual behavior perpetrated by unmarried men \\
9. Sexuality is identical to premarital sexual behavior that is commonly practiced among \\
10. Sexuality is a trend today, going without sexual behavior is considered as old-fashioned. \\
Source: Primary Data Processing (2015).
\end{tabular}


reproductive organs. There are some informants who respond it by asking to their older siblings and friends. However, many of them respond it by searching the information through internet using their smartphone. The confession from GA shows that the information provided by her older siblings and family members tends to be very convoluted. Therefore, it makes GA to feel reluctant to ask her family members when it comes to sexuality. The convoluted information given by the family to children happens because of the view from the public which views sexuality as a taboo topic. Although the present condition is in the era of modernization, it cannot be denied that topic about sexuality, for most families, is still assumed as a taboo. The condition is influenced by several factors including their knowledge, prevailing social values, education and others. The final reference for adolescents to look for information is internet because it provides various kinds of information, including information about sexuality. Common adolescents are more comfortable to access information over the internet than having to ask to consultants and parents/family members because of embarrassment and finding comprehensive information. Therefore, the information obtained by the adolescents cannot be wisely controlled, resulting in various perspectives and responses to express it.

Adolescents enjoy their age and maturity of sexuality by expressing it with a variety of activities. There are those who enjoy it in positive or negative ways. Through positive ways, most high school students use it by doing some extracurricular activities, additional tutoring related to school and sports. While through negative ways, many students spend their time by doing less useful activities, for example, hanging out with friends in the park until late at night, going on dates and some students even do extreme activities such as consuming drugs and doing premarital sex.

Related to the above negative actions done by adolescents, more specifically dealing with adolescents who spend a lot of time with negative ways such as dating, the pre- sent study reveals some interesting phenomena associated with how adolescents in Semarang express and spend their adolescence for things related to sexuality. In this study, the patterns of sexual behavior that has been done by students of Semarang can be observed.

\section{Premarital Sexual Behavior Patterns among High School Students}

Based on the results of research, premarital sexual behavior performed by some high school students in Semarang is a result of negative sexual perceptions. Premarital sexual behavior which has been conducted by high school students in Semarang is very diverse ranging from a sense of attraction to the behavior of dating, kissing, petting, to intercourse. Such premarital sexual behavior forms its own patterns in accordance with the experience and background of research subjects. The patterns of sexual behavior among high school students in Semarang can be classified based on several criteria. These criteria include premarital sexual behavior based on levels, needs/motives, partners and intensity. The classification of pre-marital sexual behavior patterns has more specific types based on the results of the study. In this discussion, researchers analyze these patterns using theories and concepts about sexuality. Figure 2 describes the patterns of premarital sexual behavior which.

Based on the field findings about behavioral patterns of adolescents in expressing their sexuality, the general sequence can be identified, namely: the early stage behavior which is characterized by imitating the grown-up adolescents toward the sensation of sexuality through information provided within media and self-service for their reproductive organs. The second stage is through by the sense of falling in love with the opposite gender which they call as dating. In this process, kissing is regarded as common among adolescents, even they start trying to touch the opposite sex body and enjoy the sensation. Furthermore, sexual sensation is obtained through genital touching (petting). The final stage of sexu- 


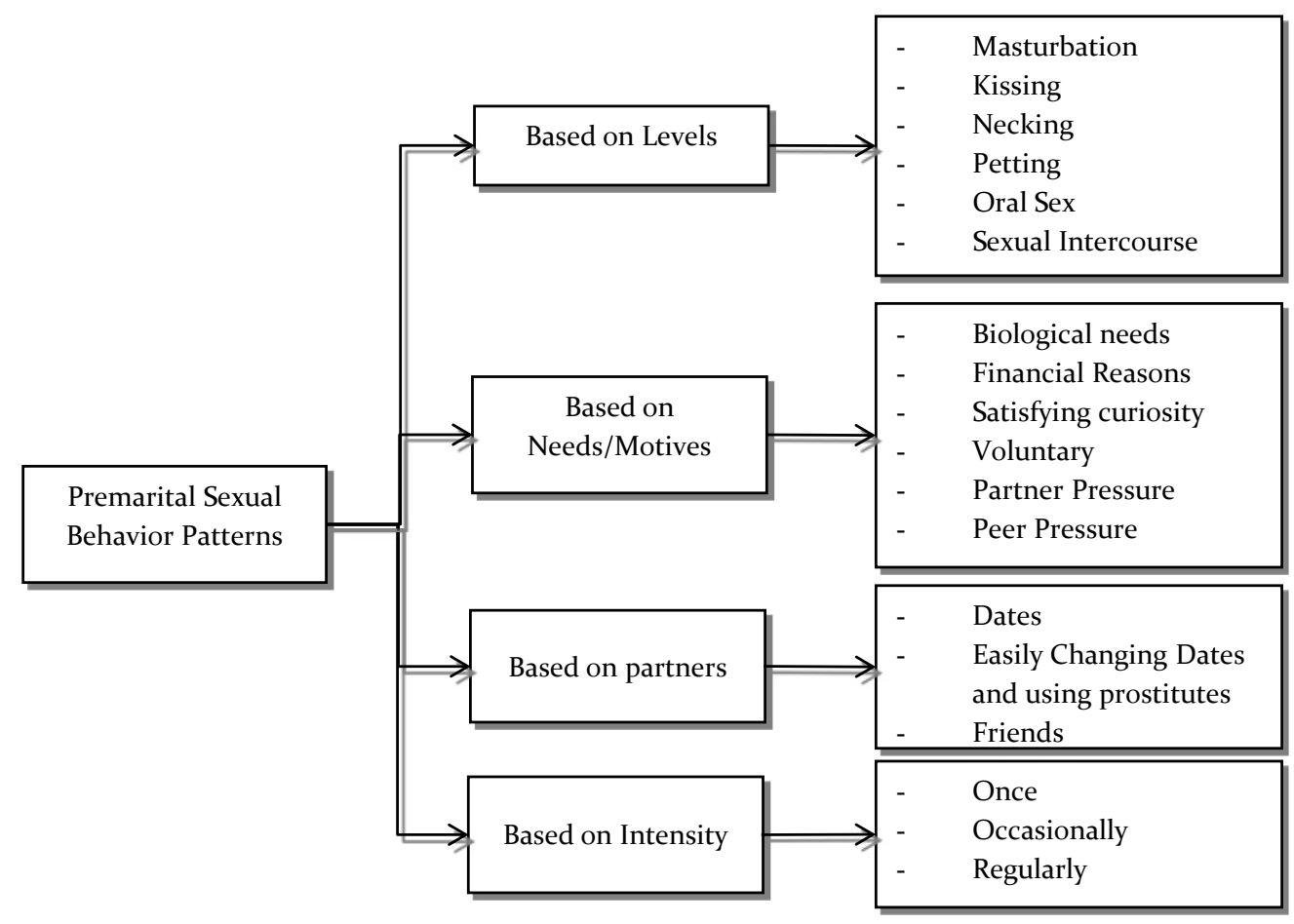

Figure 2. Sexual Behavior Patterns among High School Students in Semarang. Source (Research, 2015).

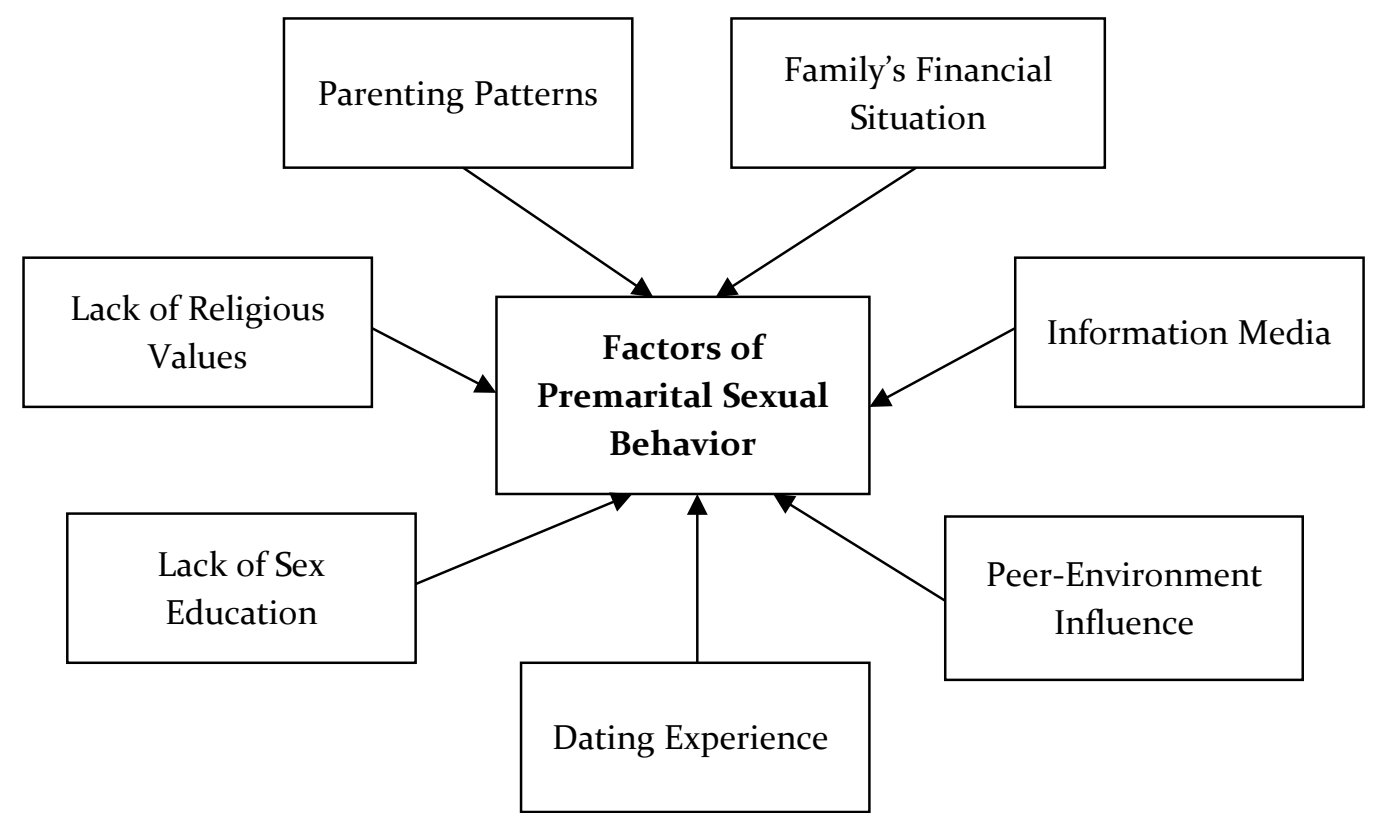

Figure 3. Factors Affecting Sexual Behavior of Adolescents in Semarang City, Semarang. Source (Research, 2015).

al sensation committed by adolescents is to perform coitus/sex with their dates. In fact, some adolescents claim to use the services of commercial sex workers in the Sunan Kuning area and do so with mutual couples.
Pre-marital sexual behavior patterns shown by adolescents in Semarang are influenced by several factors. Figure 3 describes some of the factors that influence premarital sexual behavior among adolescents. 
Based on parenting pattern in the results of the study, it is indicated that the role of parents in doing the parenting determines the behavior of students in everyday life. Related to the phenomenon of premarital sexual behavior which is spreading among adolescents, the parenting and education within families provided to adolescents is still very lacking. The condition happens because parents are usually very busy with their work. Economic condition explains why some adolescents in Semarang perform sexual behavior. The condition is because some of these teenagers receive money from their premarital sexual behavior activities. Media information greatly affects the perception of premarital sexual behavior of adolescents in Semarang. Some sources are used to gain knowledge and information about the sexuality such as from the internet, television, etc.

Dating experience is the most dominant factor in influencing student premarital sexual behavior because it is caused by the dating myths circulating in the community. These dating myths include peeping on the «women>s part» when dating is safe and riskless, making sexual relationships and other myths such as they need to sacrifice something for their dates as a proof of love. These dating myths are the ones that cause adolescents to get caught up in wrong misinterpretation of sexual behavior because the information gleaned from the social environment is accepted by them without any filter to information.

Lack of sex education, based on research results with the more widespread premarital sexual behavior among students of Semarang, proves that they are lack of sex education from the family, school and society. Sex education in the family environment is still very poor because there is an assumption that talking about the issue of sexuality is still considered taboo. At school, it is also still difficult for sex education to enter into the school curriculum independently. Lack of religious values is perceived by the teen. This condition is caused by sources of information about religion is still very limited. Therefore, the basic for reli- gious beliefs that exist in adolescents is still very weak.

\section{Adolescents Popular Terms in Ex- pressing Sexuality}

Knowledge concerning sexuality, in addition to be obtained from the internet, is also obtained from the social interaction among their peers. The interaction is not only limited with their fellow adolescents, but also with college students and working people. Therefore, there are many terms known from the interaction, for example colly, kobel, jilmek, ewe, kimcil and salome.

Table 3. Popular Sex Terms among Students

\begin{tabular}{ll}
\hline $\begin{array}{c}\text { Popular Terms } \\
\text { of Sex in Student } \\
\text { Interaction }\end{array}$ & The Word Meaning \\
\hline Colly & Shaking the penis \\
Kobel & Playing the vagina \\
Jilmek & Licking the vagina \\
Ewe / Ngentot & Intercourse \\
PS & Phone Sex \\
CS & Sex Chats \\
ST & Short time \\
LT & Long Time \\
Kimcil & Teenage prostitutes \\
Blow Job / Oral & Oral Sex \\
Sangi & Sexually high \\
Kak Edi & Premature ejaculation \\
Salome & One Hole for a lot of \\
& people \\
Anal Sex & Intercourse Through \\
& Anus \\
Perek & Prostitutes \\
Filbo & Porn Movie \\
PK & Karaoke Guide \\
\hline
\end{tabular}
Source: Primary Data Processing (2015).

The use of popular terms among adolescents in expressing sexuality is part of concealing their behavior from friends and control of their parents. In addition, the use of this slang is considered more updated. According to NA's confession, the above terms are often used by NA in expressing sexuality with her date and friends. She further said that other terms are also used in the relationship, such as sex terms deri- 
ved from Japanese and French, for example: Kimochi (Delicious), Haii (Pain), Sugoii (Fun), Iku Iku (Im 'Coming), while for the French language like: Nigue moii (please, have sex with me), Grave Grave (Harder / Louder), Donne Moi La Fesee (Touch my Butt, please). The terms above are often used by NA and her friends when hanging out and talking about sex. When talking about sex, the terms are often used so that for someone who understands the sexual behavior will understand more quickly when hanging out with friends.

Starting from the social interaction and information from the internet that is very accessible, NA knows the world of sex. NA's dating activity has led to sexual intercourse behavior. NA often has sex with her boyfriends. NA also frequently changes her boyfriends. In one month, she can change her dates twice so the sexual intercourse is done with multiple dates as well. In order to prevent this premarital sexual behavior to result in a pregnancy, NA with her partners uses safe sex by using a condom. The analysis on the action and dating interaction performed by NA show that it is no longer at the level of ordinary dating but it has led to professionalism in sex.

Sexual activities such as kissing, necking or petting, are often carried out in deserted places such as cafes with baffles or in crowded places such as on the riverside of Banjir Kanal river during afternoon or evening. As for NA, intimate relationship is often done at her boyfriends' house or dorm. The free behavior and interaction of NA remains unknown by her family. When she is at home, NA behaves like a normal adolescent. However, when she is outside, NA changes to be like an adult woman who already knows the world of sex. This condition is due to internet factors and poor parental supervision.

Based on the above findings, it can be analyzed that the social interaction among students is now experiencing a remarkable shift. The lack of values, norms and basic religion teachings affect many students to fall into the deviant behavior of premarital sexual behavior. The meaning of self-esteem for a woman is no longer a standard or a symbol that must be protected and respected. Selfesteem is an important construct of one's own behavior. In this case, young women who have had premarital sex will lead to behavior that affects her self-esteem. Female students should understand it correctly in order to protect themselves. However, what happens is the opposite. The meaning of self-esteem which is closely related to virginity is set aside by lifestyle or contemporary trend among adolescents.

\section{Building the Transition-Age of Adoles- cents in the Global Era}

Adolescents are individuals in transition from childhood into adulthood. Vulnerable adolescent ages are ranged from 12 to 21 years. Based on the age classification, adolescents are at the level of high schools, one of them is senior high school students. Senior high school students in general are mostly 17 to 18 years old. During this period, the student's psychological condition is emotionally unstable and shows more prominence and moral attitudes. They also start to build perfect mental capacity, have confusing status and many problems as well as enter a critical period. In adolescence, they are also trying to get away from their environment and bonding of parents because students want to search for identity.

This critical period and the desire to establish a new identity outside the family encourage urban adolescents try to build the identity as urban teenagers using various facilities that are easily accessible. Several efforts made by young people in shaping the contemporary identity include:

\section{The Formation of Adolescent Identity in Semarang}

The adolescent identity formation in Semarang is conducted through manipulation process of image formation which comes from completely open connection of information. The lack of control for information system in Indonesia considers that what is modern is always considered the best, especially for adolescents who need recognition from society and the environment. The 
change of capitalistic global era is able to demolish identities as noble personality of local communities. The variety of products offered through superior image eventually erodes the local identities that are originally considered as polite, friendly, and obey the social principle. The presence of identity in the form of the image cannot be avoided any more by Indonesian people, especially for adolescents.

Therefore, what is shown by adolescents in Semarang on the identity of selfhood is the product of identity connectivity and the fading of local culture because of outside identity which are considered as superior and modern. As the confession from an informant named Ricky:

“... I usually use the branded stuffs, Mas ... if I do not use the branded ones, I feel embarrassed, especially when it comes to gadget. It must be completely up to date. If it is outdated .... I'm embarrassed with my friends ..."

The above confession is reaffirmed by Chynta,:

"I'm a girl, Mas, so I am different with a guy. If I am not socially mingle with others, I won't sell, right? So my makeup, clothing, and appearance must be considered correctly. If I don't, I will not exist ... I cannot can get awesome friends ... so I should look as great as possible, Mas ... whatever happens, I must be updated ... like in the Korean movies, you know, Mas.. “

\section{Identity and Adulthood of Adolescent Behavior: Biological-Fulfillment of Meeting the Needs for Sex}

In adolescence period, there is not much activity done by children. Their main job is to learn both from formal education and as a member of the community. Unfortunately, young people in the city with one of its individualistic nature, learning to be accepted by the public is less cause for concern. The main focus is learning through formal education institutions, which apparently serves as ritualistic habit. The empty spaces in the above process are not utilized properly by the city adolescents. They even try to build identity of adolescents which are considered modern and updated. The updated adolescents adopt popular culture that is being considered as current trend.

All kinds of fulfillment of sexuality ranging from self-service until real sex are performed without their parents knowing about it. This happens because of the lack of openness of parents and children in the family in terms of sexuality and personal relationships. Some even claim that they do not know whether their children are in a relationship with other teenagers. Ironically, there are parents who are apathetic to their children's social interaction. Parents do not quite know their children's friends and what they do outside school hours.

\section{The Channel for Adolescent Identity in Semarang}

The dynamics of adolescent identity formation as a consequence of the global era is further complicated by external forces rather than internal strength. Of all the development process undertaken in developing countries, including in Indonesia, strengthening the modernization of the public wealth instead of preserving the potential of natural, social and cultural society is always happening. Government should offer programs that promote physical development. Consequently, there is public's perspective which believes that the modern suitability is aligned with the mission and the behavior offered by capitalism and the global era.

The incarnation of capitalism in the city has changed the lifestyle of community, including adolescents. In addition to it, the emergence of the capitalists fanatical groups in Indonesia also helps strengthening and modernizing the construction of an increasingly consumerist urban adolescents. The channeling process of identity building of city adolescents which has been running continuously experiences distorted identity, both from packaging capitalist power through the media, also the strength of militant groups that have been formed by capitalism products. From the interpretation of the obtained data, it can be classified that 
adolescents attempt to establish the identity of contemporary adolescents who can be reached through three channels, namely: Branding Personality, Meeting the Needs of Adolescents Sexuality, and Achievement.

\section{The Role of Family in Educating Ado- lescents from Capitalism}

The economic condition of a family, especially for the parents of high school students in Semarang, is mostly from middle to high economy. However, there are some families which are categorized as lower-middle families. Based on the present study, there is a unique finding stating that the economic condition of parents who belong to the middle and upper or lower have a common thread between both of them related to the role of the presence of their parents. Economic background of the family of both types of classes are taken for work, so the result of that is the concern of parents of children somewhat less and cannot cover all of the child's behavior, especially when their children are out of the house.

According to the research, most parents of the students are working. Parents' jobs which require them to spend much time outside tend to make the parents do not know their children's daily activities. Lack of education taken by the person also influences the pattern of care provided for the children. In terms of social relationships, such as parents are more likely to let their children (students) to play with anyone, anywhere and anytime. They are not used to observe the development of adolescents psychologically, biologically and socially. Based on these economic conditions, many teens find satisfaction in functional family outside the family through other people or the media, instead of the parents (family members).

The narrative of adolescent behavior with their global era makes family roles destroyed by the physical needs (material), while parents are busy with work outside the home. Globalization causes the fading of local cultural identity because globalization is an arena/field of symbolic battles in which ongoing struggle for power over the sources of culture (Piliang 2008, p. 135). The flurry of parents at work causes the absences of intimacy in relationships within the family structure. As a result, the roles of parents in a family over children have been widely replaced by babysitter, electronic media, and institutions / particular institutions that are not necessarily teaching social ethics. The pressure of capitalist against the duty of parents has resulted in a map division of the parents becomes gray without control and a clear role.

The challenge of being a parent in the household of past and present is very different. This condition can be seen in the family residing in urban areas. In the social conditions of families that exist in urban challenge in the face of globalization is much larger than families in rural areas. Various technologies, lifestyles and social values began to shift into a challenge for families residing in urban areas. Rural families are differences with the family residing in urban areas. The past or family who live in rural areas occupy many areas are still isolated, so the responsibility of parents is to direct their children to the social world in accordance with the culture of local people. Other than that, control of the public to educate the children to become members of society and into one of the successes of children to become members of society personally and socially.

The parents of adolescents who are the subjects of the study claim that in fact, as parents, they have already fulfill their duties. Even, their parents keep on lecturing and directing their children to obey the ethics most of the time, such as the confession of IL's mother:

\footnotetext{
"Sometimes, working outside of the house demands me the way it needs to be. The energy is drained home from work, sometimes what I do toward my children is sometimes still valued less by children, but what I do is for the sake of my children, Mbak".

While IL's confession is as follows:

“.... if I am at home, my mom often lectures me, especially when I just get back from hanging out with my friends. She de-
} 
finitely asks me. Although I am not doing anything -I do not even have a boyfriend and I just hang out with my casual girl classmates, she is always worried. She says that she does not want something bad happens to me".

Parents who go into the public sector also admit that the decision to the chose public sector is to guarantee the children in the household. In addition, parents have tried very hard to use leisure time for quality time with family members. The free time can be spent by getting some vacation or just chatting among family members to familiarize themselves with each other. As for adolescents in the family, the intimacy of the family is unable to satisfy the challenges of being an adolescent. Today's issues are now much more complex than the issues that adolescents in an earlier era. Adolescents admit that parental control is mostly done through mobile media. Such action creates discontent of adolescents to enjoy the functions of the family.

The role of parents in the capitalist era, either consciously or not, has become an intermediary media for capitalism. It means that families have become a vehicle for the delivery of commercial messages from the hands of the capitalist producer of capital owners. This illustrates the reality that an ad packaging is also able to act as a mirror reflecting the spirit of its era. The greed of consumerism and hedonism is constantly preserved. Through the manipulation of symbols and mental engineering, a group of venture capitalists exploits industry leading technology and imaging media (audio, visual, audiovisual, and interactive), resembling imaginary reality to become the orientation of the formation of lifestyle in a real life. The fulfillment of adolescents' needs by their parents which is solely based on the physical /material needs has led adolescents to be consumptive.

The obligation of parents and community is to describe a never ending process to continuously keep the adolescents' identity based on the personality of a noble nation. Parents and society must not be ab- sent in providing new models and controls for shaping up the identity of adolescents. This effort is a responsive form that needs to be done by parents so their children will not experience confusion or even lose their identity as a positive adolescent (especially in terms of sexuality).

\section{CONCLUSION}

Adolescence is filled with liminal identity used by the city adolescents to identify and construct themselves as updated adolescents within a technologically sophisticated world. This self-construction effort cannot be separated from the physical changes in response to biological desire. The efforts to construct themselves with the distribution of incorrect information media and the reluctance of families to share information on how to respond adolescence affect the sexual behavior of urban adolescents. In addition, the shift of family role which puts the economy needs first serves as a big role in misconceptions of adolescents in responding the symptoms of body miss-adaptation in a global era. Through this research, the initial assumption becomes clear that the process of identity formation for adolescents is a dialectical process between, adolescence transition period, the role of family, an open global information systems and the spirit of capitalism which brings consumptive and hedonistic lifestyle.

Based on the above data presentation, some recommendations are given in order to prevent the negative adolescent behaviors, namely; the needs for raising awareness and strengthening the function of the family as the smallest unit within society to internalize several social values according to Indonesian values and personalities upheld by local culture, the needs for socialization on reproductive health and sex education for adolescents who are taught through peer guides which is expected to help young people to construct an appropriate understanding and formation of local cultures and values, and the needs to construct a comprehensible socialization agent and proper channels for the growth and development of adolescents 
to avoid misinterpretation of the concept of sexuality and other issues.

\section{REFERENCES}

Burton, C. M., Marshal, M. P., Chisolm, D. J., Sucato, G.S., \& Friedman, M. S., 2013. Sexual minorityrelated victimization as a mediator of mental health disparities in sexual minority youth: A longitudinal analysis. Journal of youth and adolescence, 42(3), pp. 394-402.

Calzo, J. P., Antonucci, T. C., Mays, V. M., \& Cochran, S. D., 2011. Retrospective recall of sexual orientation identity development among gay, lesbian, and bisexual adults. Developmental psychology, 47(6), pp. 1658.

Cherie, A. \& Yemane, B., 2012. Peer Pressure Is the Prime Driver of Risky Sexual Behaviors among School Adolescents in Addis Ababa, Ethiopia. World Journal of AIDS, 1(7), pp. 1-12.

DiFulvio, G. T., 2011. Sexual minority youth, social connection and resilience: From personal struggle to collective identity. Social Science \& Medicine, 72(10), pp. 1611-1617.

Everett, B. G., 2013. Sexual orientation disparities in sexually transmitted infections: examining the intersection between sexual identity and sexual behavior. Archives of sexual behavior, 42(2), pp. 225-236.

Kusumastuti, F. A. D., 2010. Hubungan antara Pengetahuan dengan Sikap Seksual Pranikah Remaja. Tesis, Fakultas kedokteran, Universitas Sebelas Maret Surakarta.

Maikovich-Fong, A. K., \& Jaffee, S. R., 2010. Sex differences in childhood sexual abuse characteristics and victims' emotional and behavioral problems: Findings from a national sample of youth. Child abuse E neglect, 34(6), pp. 429437.

Oljira, L., 2012. Pre-marital Sexual Debut and Its Associated Factors Among In-School Adolescents In Eastern Ethiopia. Jurnal BMC Public Health,1 (1), pp. 1-13.

Piliang, A.Y., 2008. Reposisi, reinterpretasi dan reimajinasi keindonesiaa: membangun bangsa melalui kreativitas dalam 'Reinventing Indonesia: Menemukan Kembali masa Depan Bangsa. MIZAN, Jakarta

Purwandari, E., 2011. Keluarga, Kontrol Sosial, dan "Strain": Modelkontinuitas Delinquency Remaja'. Jurnal Humanitas, 8(1), pp. 1-17.
Putri, N.A., 2014. Persepsi Seksualitas Kalangan Pelajar SMA/MA di Kota Semarang (Studi Kasus terhadap Bentuk Penyimpangan Sosial Perilaku Seksual Pranikah pada Pelajar SMA/ MA di Kecamatan Gunungpati). Tesis. Program Pascasarjana, Universitas Negeri Semarang.

Rachman, M., 1999. Strategi dan Langkah-Langkah Penelitian. IKIP Semarang Press, Semarang

Renaud, J., Berlim, M.T., Begolli, M., McGirr, A., \& Turecki, G., 2010. Sexual orientation and gender identity in youth suicide victims: An exploratory study. The Canadian Journal of Psychiatry, 55(1), pp. 29-34.

Ringrose, J., 2011. Are you sexy, flirty, or a slut? Exploring 'sexualization'and how teen girls perform/ negotiate digital sexual identity on social networking sites. New femininities: Postfeminism, neoliberalism and subjectivity, pp. 99-116.

Schensul, S. L., Schensul J. J., \& LeCompte, M. D., 1999. Essential Ethnographic Methods: Observations, Interviews, and Questionnaires. AltaMira Press, California

Stone, D. M., Luo, F., Ouyang, L., Lippy, C., Hertz, M. F., \& Crosby, A. E., 2014. Sexual orientation and suicide ideation, plans, attempts, and medically serious attempts: Evidence from local youth risk behavior surveys, 20012009. American journal of public health, 104(2), pp. 262-271.

Suryanto \& Kuwatono, 2010. Peran Media Massa dalam Perilaku Seksual Remaja di Kota Semarang. Jurnal Semai Komunikasi, 1(1), pp..15-31.

Synanti \& Zalbawi S., 2001. Perlaku Seks di Kalangan Remaja dan Permasalahannya. Jurnal Media Litbang, 9(1), pp. 1-6.

Walls, N.E., Kane, S.B., \& Wisneski, H., 2010. Gaystraight alliances and school experiences of sexual minority youth. Youth \& Society, 41(3), pp. 307-332.

WHO Geneva. 1986. Young People's Healthy Challenge for Society. WHO, Geneva.

Wulandari, I., 2010. Hubungan Pola Asuh Demokratis dengan Sikap terhadap Perilaku Seksual Remaja. Skripsi, Program studi Psikologi, Fakultas Ilmu Sosial Humaniora, UIN Sunan Kali Jaga, Yogyakarta

Yulianto. 2010. Gambaran Sikap Siswa SMP terhadap Perilaku Seksual Pranikah (penelitian dilakukan di SMPN 159 Jakarta). Jurnal Psikologi, 8(2), pp. 1-13. 